\title{
Utilization of watermelon seed flour as protein supplement in cookies
}

\author{
Tusneem Kausar*, Muhammad Tahir Hassan and Ghulam Mueen ud Din \\ Institute of Food Science and Nutrition, University of Sargodha, Sargodha, 40100-Pakistan \\ *Corresponding author's email: tusneem.kausar@uos.edu.pk \\ Citation \\ Tusneem Kausar, Muhammad Tahir Hassan and Ghulam Mueen ud Din. Utilization of watermelon seed flour as \\ protein supplement in cookies. Pure and Applied Biology. Vol. 9, Issue 1, pp202-206. \\ http://dx.doi.org/10.19045/bspab.2020.90024
}

\begin{tabular}{llll}
\hline \hline Received: 16/07/2019 & Revised: 19/09/2019 & Accepted: 20/09/2019 & Online First: 04/10/2019 \\
\hline \hline
\end{tabular}

\section{Abstract}

Watermelon seeds are by-product of watermelon, rich in fat and proteins and normally discarded. The present research is planned to use watermelon seed flour as protein supplement in formulation of cookies at $0,10,20,30$ and $40 \%$ substitute with wheat flour. The results of the present study indicated that samples of watermelon seed flour added cookies contain more proteins $(12.47 \%)$, fat $(21.75 \%)$, ash $(1.85 \%)$ and fibre $(2.36 \%)$ as compared to cookies without watermelon seed flour samples, significantly. Addition of watermelon seed flour affects the physical parameters of cooking by decreasing the spread factor. However, panelists for sensory evaluation accept the cookies containing watermelon seed flour at all concentrations in terms of color, crispiness, flavor, texture and overall acceptability. So, watermelon seed flour can be used for preparation of cookies with improved protein, fat, fibre and ash content.

Keywords: Cookies; Physico-chemical parameters; Protein supplement; Sensory properties; Watermelon seed flour

\section{Introduction}

Watermelon (Citrullus lanatus) is a vine like drought annual flowering plant originated in Southern Africa. It is enriched with nutrients i.e. vitamin $\mathrm{A}, \mathrm{B}_{6}$ and $\mathrm{C}$, lycopene, antioxidants and amino acids. Its water content $(92 \%)$ keeps hydrated and full of electrolytes which help to prevent from heat stroke. Pakistan ranks $30^{\text {th }}$ in water melon production and its share is only $0.3 \%$ in the world. In Pakistan, utilization of water melon fruit is limited to the direct consumption of fresh fruits [1]. In food industry, water melon pulp is used for preparation of cocktails, juices and nectars. Processing of fruits and vegetables generate a large amount of residues which cause disposal and environmental problems. The rind and seeds are usually discarded. In some countries, rind is used as vegetable after cooking. Watermelon rind is also a rich source of natural fibre and studied to increase fibre content in cakes [2]. It is [3] also recommended to the use of watermelon rind powder to improve health promoting nutraceutial and functional properties for the production of cookies. On the other hand, watermelon seeds are rich in fats and proteins and can be added in different foods as a protein source and fat replacement [4].

Proteins from plant sources have been getting importance as their enrichment in food has been increasing among health conscious people and vegetarians [5]. However, it's needed that enrichment should not change functional and organoleptic characteristics of 
final product $[6,7]$. In addition, these protein enriched product should meet consumer expectation in terms of satisfaction, nutrition and affordability [8].

Cookies are the most popularly consumed bakery items for all age groups due to affordable cost, ready to eat nature, good nutritional quality, longer shelf life and availability in different tastes [9]. So, the present study was planned to add watermelon seed flour as protein supplement in cookies and to evaluate its effect on physical, chemical and organoleptic acceptability of cookies.

\section{Materials and methods}

Preparation of watermelon seed flour

Watermelon seeds were purchased from local market, Sargodha, Pakistan, ground into powder and sieved to get powder with an average particle size of $65 \mu \mathrm{m}$. Proximate composition of this powder was assessed by the methods described in AOAC [10]. Powder was then stored in polyethylene bags till further use.

\section{Preparation of cookies}

Cookies from wheat flour replacing watermelon seed flour at 0, 10, 20, 30 and $40 \%$ were prepared according to method No. 10-53.01 as described in AACC [11].

\section{Physical analysis of cookies}

Biscuits were evaluated for their physical parameters like diameter $(\mathrm{mm})$, thickness $(\mathrm{mm})$ and spread ratio (diameter/thickness) according to described method of AACC [11].

\section{Chemical composition of cookies}

Moisture, protein, fat, ash, fiber and NFE contents were determined according to the official methods of the AOAC [10]. All analysis were performed in triplicate.

\section{Sensory evaluation of biscuits}

Sensory evaluation was conducted using a semi-trained panel of twenty judges. Coded samples of cookies were presented to each of the judges and they were asked to assess the biscuits for color, texture, taste, aroma and overall acceptability according to the procedure described by [12].

\section{Statistical analysis}

Results obtained were subjected to analysis of variance (ANOVA) and the means were compared using LSD as described by [13].

\section{Results and discussion}

Proximate composition of watermelon seed flour

Table 1 shows the proximate composition of watermelon seed flour. The results obtained are similar to the results reported by $[14,15]$ who used watermelon seed powder for preparation of cookies and soup, respectively.

\section{Physical properties of cookies}

The effect of replacing $0,10,20,30$ and $40 \%$ of wheat flour with watermelon seed flour on physical properties of cookies was studied and the data are showed in (Table 2). The results revealed that all selected treatments caused significant decrease in diameter of cookies as compared to the control (59.67 $\mathrm{mm}$ ) except $10 \%$ of watermelon seed flour added cookies given diameter significantly equal to control $(57.33 \mathrm{~mm})$. It was also clear that using watermelon seed flour at all levels in cookies preparations resulted in significant increase in thickness when compared with $7.50 \mathrm{~mm}$ for control. The higher thickness $(14.5 \mathrm{~mm})$ was recorded at $40 \%$ watermelon seed flour. Decrease in diameter in watermelon seed flour added cookies can be due to dilution of gluten. Concerning the spread ratio, it was observed that replacing wheat flour with watermelon seed flour decrease the spread ratio except of $\mathrm{T}_{1}$ where replacement is $10 \%$. These results are in line with those obtained by [61]. It was [17] also reported that addition of apricot seed flour and fiber-rich fruit powders reduce the spread ratio values of cookies.

\section{Chemical composition of cookies}

Chemical composition of cookies prepared with watermelon seed flour by replacing wheat flour at $0,10,20,30$ and $40 \%$ showed 
that addition of watermelon seed flour increase fat, protein, fibre and ash content significantly as compared to control (Table 3 ). Lowest moisture content was observed in $\mathrm{T}_{0}(6.93 \%)$ and highest score was found in $\mathrm{T}_{4}$ (8.27). It was also reported that addition of mango peel and mango seed powder increased the moisture content in various samples [16]. Watermelon seed flour supplemented biscuits showed higher moisture content than control. This can be due to hygroscopic nature of seed flour. The highest fat content (21.75), protein content (12.47), fibre (2.30) and ash (1.85) was found to be in $\mathrm{T}_{4}$ (having $40 \%$ watermelon seed flour). As shown in (Table 1), watermelon seed flour contains fat 46.78, protein 26.37, fiber 4.10 and ash 3.73. Thus, the addition of watermelon seed flour increases this content in cookies. [18] reported that apricot kernel flour is high in proteins, fat and total dietary fibre and addition of this flour increase proteins, fat and dietary fiber in cookies.
Similar findings were observed in biscuits prepared by adding mango peel and seed [19].

\section{Sensory characteristics of cookies}

The sensory parameter (color, crispiness, flavor, texture and overall acceptability) of the cookies supplemented with watermelon seed flour were and results are show in (Table 4). Color and crispiness of cookies prepared by replacing wheat flour with watermelon seed flour were improved while scores for flavor and texture were affected but still fall in the acceptable level in the nine-point hedonic scale. However, overall acceptability was not affected and remain non-significant in all samples with and without watermelon seed flour added cookies ( $p>0.05$ ).

Results showed that texture was affected by addition watermelon seed flour. This can be due to increased water absorption which can result in harder texture. Results of sensory evaluation are similar to that of [16].

Table 1. Proximate composition of watermelon seed flour

\begin{tabular}{|c|c|}
\hline Parameter & Composition (\%) \\
\hline Moisture & 8.25 \\
\hline Ash & 3.73 \\
\hline Crude fat & 46.78 \\
\hline Crude protein & 26.37 \\
\hline Crude fiber & 4.10 \\
\hline Carbohydrates & 10.77 \\
\hline
\end{tabular}

Table 2. Effect of watermelon seed flour on physical properties of cookies

\begin{tabular}{|c|c|c|c|}
\hline \multirow{2}{*}{ Treatments } & Width $(\mathbf{m m})$ & Thickness $(\mathbf{m m})$ & Spread factor \\
\hline $\mathrm{T}_{0}$ & $59.67^{\mathrm{a}}$ & $7.50^{\mathrm{d}}$ & $7.99^{\mathrm{a}}$ \\
\hline $\mathrm{T}_{1}$ & $57.33^{\mathrm{ab}}$ & $8.33^{\mathrm{d}}$ & $6.99^{\mathrm{a}}$ \\
\hline $\mathrm{T}_{2}$ & $55.33^{\mathrm{b}}$ & $10.67^{\mathrm{c}}$ & $5.20^{\mathrm{b}}$ \\
\hline $\mathrm{T}_{3}$ & $52.3 \mathrm{c}^{\mathrm{b}}$ & $13.00^{\mathrm{b}}$ & $4.05^{\mathrm{bc}}$ \\
\hline $\mathrm{T}_{4}$ & $49.00^{\mathrm{d}}$ & $14.50^{\mathrm{a}}$ & $3.38^{\mathrm{c}}$ \\
\hline
\end{tabular}

${ }^{\mathrm{a}-\mathrm{d}}$ Mean values in column with different superscript are significantly different $(\mathrm{p}<0.05)$.

$\mathrm{T}_{0}$ : Cookies with $0 \%$ watermelon seed flour and 100 wheat flour

$\mathrm{T}_{1}$ : Cookies with $10 \%$ watermelon seed flour and $90 \%$ wheat flour

$\mathrm{T}_{2}$ : Cookies with $20 \%$ watermelon seed flour and $80 \%$ wheat flour

$\mathrm{T}_{3}$ : Cookies with $30 \%$ watermelon seed flour and $70 \%$ wheat flour

$\mathrm{T}_{4}$ : Cookies with $40 \%$ watermelon seed flour and $60 \%$ wheat flour 
Table 3. Effect of watermelon seed flour on chemical characteristics of cookies

\begin{tabular}{|c|c|c|c|c|c|c|}
\hline Treatments & Moisture & Fat & Protein & Fibre & Ash & NFE \\
\hline $\mathrm{T}_{0}$ & $6.93 \pm 0.04^{\mathrm{a}}$ & $15.67 \pm 0.26^{\mathrm{e}}$ & $8.48 \pm 0.16^{\mathrm{d}}$ & $1.90 \pm 0.01 \mathrm{e}$ & $1.40 \pm 0.01^{\mathrm{e}}$ & $64.28 \pm 1.62^{\mathrm{a}}$ \\
\hline $\mathrm{T}_{1}$ & $7.00 \pm 0.10^{\mathrm{a}}$ & $17.08 \pm 0.40^{\mathrm{d}}$ & $9.73 \pm 0.15^{\mathrm{c}}$ & $1.97 \pm 0.02^{\mathrm{d}}$ & $1.47 \pm 0.01^{\mathrm{d}}$ & $61.72 \pm 1.08^{\mathrm{b}}$ \\
\hline $\mathrm{T}_{2}$ & $7.47 \pm 0.27^{\mathrm{b}}$ & $18.54 \pm 0.41^{\mathrm{c}}$ & $10.97 \pm 0.12^{\mathrm{b}}$ & $2.05 \pm 0.07^{\mathrm{c}}$ & $1.56 \pm 0.06^{\mathrm{c}}$ & $59.41 \pm 0.78^{\mathrm{c}}$ \\
\hline $\mathrm{T}_{3}$ & $8.03 \pm 0.49^{\mathrm{c}}$ & $19.91 \pm 0.33^{\mathrm{b}}$ & $11.21 \pm 0.12^{\mathrm{ab}}$ & $2.24 \pm 0.05^{\mathrm{b}}$ & $1.72 \pm 0.06^{\mathrm{b}}$ & $57.92 \pm 0.74^{\mathrm{d}}$ \\
\hline $\mathrm{T}_{4}$ & $8.27 \pm 0.87^{\mathrm{d}}$ & $21.75 \pm 0.58^{\mathrm{a}}$ & $12.47 \pm 0.07^{\mathrm{a}}$ & $2.36 \pm 0.03^{\mathrm{a}}$ & $1.85 \pm 0.03^{\mathrm{a}}$ & $54.64 \pm 0.49^{\mathrm{e}}$ \\
\hline
\end{tabular}

Mean \pm Standard deviation

a-e Mean values in column with different superscript are significantly different $(\mathrm{p}<0.05)$.

$\mathrm{T}_{0}$ : Cookies with $0 \%$ watermelon seed flour and 100 wheat flour

$\mathrm{T}_{1}$ : Cookies with $10 \%$ watermelon seed flour and $90 \%$ wheat flour

$\mathrm{T}_{2}$ : Cookies with $20 \%$ watermelon seed flour and $80 \%$ wheat flour

$\mathrm{T}_{3}$ : Cookies with $30 \%$ watermelon seed flour and $70 \%$ wheat flour

$\mathrm{T}_{4}$ : Cookies with $40 \%$ watermelon seed flour and $60 \%$ wheat flour

Table 4. Effect of watermelon seed flour on sensory evaluation of cookies

\begin{tabular}{|c|c|c|c|c|c|}
\hline Treatment & Color & Crispness & Flavor & Texture & Overall acceptability \\
\hline $\mathrm{T}_{0}$ & $7.80 \pm 0.37^{\mathrm{a}}$ & $5.80 \pm 0.80^{\mathrm{b}}$ & $7.80 \pm 0.37^{\mathrm{a}}$ & $8.00 \pm 0.45^{\mathrm{a}}$ & $8.00 \pm 0.55^{\mathrm{a}}$ \\
\hline $\mathrm{T}_{1}$ & $8.00 \pm 0.45^{\mathrm{a}}$ & $6.00 \pm 0.45^{\mathrm{b}}$ & $7.50 \pm 0.45^{\mathrm{a}}$ & $7.80 \pm 0.37^{\mathrm{ab}}$ & $8.10 \pm 1.00^{\mathrm{a}}$ \\
\hline $\mathrm{T}_{2}$ & $8.20 \pm 0.37^{\mathrm{a}}$ & $7.60 \pm 0.51^{\mathrm{a}}$ & $7.10 \pm 0.51^{\mathrm{a}}$ & $7.80 \pm 0.37^{\mathrm{ab}}$ & $8.72 \pm 0.93^{\mathrm{a}}$ \\
\hline $\mathrm{T}_{3}$ & $8.60 \pm 0.24^{\mathrm{a}}$ & $8.60 \pm 0.24^{\mathrm{a}}$ & $7.00 \pm 0.71^{\mathrm{a}}$ & $7.20 \pm 0.49^{\mathrm{ab}}$ & $8.21 \pm 1.03^{\mathrm{a}}$ \\
\hline $\mathrm{T}_{4}$ & $8.40 \pm 0.40^{\mathrm{a}}$ & $8.60 \pm 0.40^{\mathrm{a}}$ & $6.40 \pm 0.81^{\mathrm{a}}$ & $6.40 \pm 0.81^{\mathrm{b}}$ & $8.52 \pm 0.68^{\mathrm{a}}$ \\
\hline
\end{tabular}

Mean \pm Standard deviation

${ }^{a-b}$ Mean values in column with different superscript are significantly different $(\mathrm{p}<0.05)$.

$\mathrm{T}_{0}$ : Cookies with $0 \%$ watermelon seed flour and 100 wheat flour

$\mathrm{T}_{1}$ : Cookies with $10 \%$ watermelon seed flour and $90 \%$ wheat flour

$\mathrm{T}_{2}$ : Cookies with $20 \%$ watermelon seed flour and $80 \%$ wheat flour

$\mathrm{T}_{3}$ : Cookies with $30 \%$ watermelon seed flour and $70 \%$ wheat flour

$\mathrm{T}_{4}$ : Cookies with $40 \%$ watermelon seed flour and $60 \%$ wheat flour

\section{Conclusion}

It is concluded that watermelon seed flour can be utilized successfully for the preparation of cookies with improved protein, fat, fiber and ash content without affecting the sensory acceptability of final product.

\section{Authors' contributions}

Conceived and designed the experiments: MT Hassan \& T Kausar, Performed the experiments: MT Hassan, Analyzed the data: MT Hassan, $T$ Kausar \& GM Din, Contributed reagents / materials/ analysis tools: MT Hassan \& T Kausar, Wrote the paper: T Kausar \& MT Hassan.

\section{References}

1. ZTBL (2019). Cultivation of watermelon. Zarai Taraqiati Bank
Limited. Planning \& Research Department. $\quad$ www.ztbl.com.pk. Approached on 8-7-19.

2. Al-Sayed HMA \& Ahmed AR (2013). Utilization of watermelon rinds and sharlyon melon peels as a natural source of dietary fiber and antioxidants in cake. Ann Agr Sci 58: 83-95.

3. Naknaen P, Itthisoponkul T, Sondee A \& Angsombat N (2016). Utilization of watermelon rind waste as a potential source of dietary fiber to improve health promoting properties and reduce glycemic index for cookie making. Food Sci Biotechnol 25(2): 415-424.

4. El-Adaway TA \& Taha KM (2011). Characteristics and composition of 
different seed oil and flours. Food chem 74: 47-54.

5. $\mathrm{Wu} \mathrm{YV}$, Hareland GA \& Warner $\mathrm{K}$ (2001). Protein-enriched spaghetti fortified with corn gluten meal. J Agric Food Chem 49: 3906-3910.

6. Topgul LM (1996) Effect of different drying conditions and cooking in pasta quality and some nutrients. Dissertation, Ege University, Izmir, Turkey.

7. Morad MM, El-Magoli SB \& Afifi SA (1980). Macaroni supplemented with lupin and defatted soybean flours. $J$ Food Sci 45: 404-405.

8. Ugarcic-Hardi Z, Hackenberger D, Subaric D \& Hardi J (2003). Effect of soy, maize and extruded maize flour addition on physical and sensory characteristics of pasta. Ital J Food Sci 15: 277-286.

9. Gandhi AP, Kotawaliwale N, Kawalkar J, Srivastava DC, Parihar VS \& Raghu Nadh P (2001). Effect of incorporation of defatted soy flour on the quality of sweet biscuits. J Food Sci Technol 38: 502-503.

10. AOAC (2000) Official Methods of Analysis (17 $7^{\text {th }}$ Ed.). Arlington, VA: Association of Official Analytical Chemists, AOAC International.

11. AACC (2000) Aproved Methods of The American Association of Cereal Chemists. Published by American Association of Cereal Chemists. $10^{\text {th }} \mathrm{Ed}$. St. Paul, Minnesota, USA.

12. Meilgaard M, Civile GV \& Carr BT (2007). Sensory Evaluation Techniques 4th Edition. Florida, USA: CRC Press.1464
13. Steel RGD, Torrie JH \& Dickey DA (1997) Principles and procedures of statistics. A biometrical approach. Singapore. $3^{\text {rd }}$ Ed. McGraw Hill Book Co. Inc., New York, USA. Pp: 400-428.

14. Ubber SC \& Akobundu ENT (2009). Quality characteristics of cookies from composite flours of watermelon seed, cassava and wheat. Pak J Nutrition 8(7): 1097-1102.

15. Akusu MO \& Kiin-Kabari DB (2015). Comparative studies on the physciochemical and sensory properties of watermelon (Citrullus lanatus) and melon (Citrullus vulgaris) seed flours used in "EGUSI" soup preparation. $J$ Food Research 4(5): 1-8.

16. Ashoush IS \& Gadallah MGE (2011). Utilization of mango peels and seed kernels powders as sources of phytochemicals in biscuit. $W J$ Dairy Food Sci 6(11): 35-42.

17. Ozbas OO, Seker IT \& Gokbulut I. (2014). Effect of apricot kernel flour and fiber-rich fruit powders on low-fat cookie quality. Turkish J Agri Natural Sci 1: 1326-1332.

18. Seker IT, Ozbas OO, Gokbulut I, Ozturk S \& Koksel H (2010). Utilization of apricot kernel flour as fat replacer in cookies. J. Food Proc Preserv 34(1): 1526.

19. Aslam HKW, Raheem MIU, Ramzan R, Shakeel A, Shoaib M \& Sakandar HA (2014). Utilization of mango waste material (peel, kernel) to enhance dietary fiber content and antioxidant properties of biscuit. J Glob Innov Agric Soc Sci 2(2): 76-81. 